\title{
The Effect of Mg Dopant and Oxygen Partial Pressure on Microstructure and Phase Transformation of $\mathrm{ZnTiO}_{3}$ Thin Films
}

\author{
Lay Gaik Teoh, ${ }^{1}$ Wei-Hau Lu, ${ }^{2}$ Ting Hsiang Lin, ${ }^{2}$ and Ying-Chieh Lee ${ }^{2}$ \\ ${ }^{1}$ Department of Mechanical Engineering, National Pingtung University of Technology \& Science, Pingtung 91201, Taiwan \\ ${ }^{2}$ Department of Materials Engineering, National Pingtung University of Technology \& Science, Pingtung 91201, Taiwan
}

Correspondence should be addressed to Ying-Chieh Lee, yclee@mail.npust.edu.tw

Received 13 October 2011; Revised 2 December 2011; Accepted 3 December 2011

Academic Editor: Fathallah Karimzadeh

Copyright () 2012 Lay Gaik Teoh et al. This is an open access article distributed under the Creative Commons Attribution License, which permits unrestricted use, distribution, and reproduction in any medium, provided the original work is properly cited.

\begin{abstract}
Mg-doped zinc titanate $\left(\mathrm{ZnTiO}_{3}\right)$ films were prepared using RF magnetron sputtering. Subsequent annealing of the as-deposited films was performed at a temperature ranging from 600 to $900^{\circ} \mathrm{C}$ for 2 hours with a heating rate of $5^{\circ} \mathrm{C} / \mathrm{min}$ in air. It was found that the as-deposited films were amorphous and contained 2.77 at.\% magnesium. This was further confirmed by the onset of crystallization that took place at annealing temperatures of $600^{\circ} \mathrm{C}$. The results showed that single $\mathrm{Zn}_{2} \mathrm{Ti}_{3} \mathrm{O}_{8}$ phase was existed at $600^{\circ} \mathrm{C}$. When annealing is at $700^{\circ} \mathrm{C}$, the results revealed that mainly a hexagonal $\mathrm{ZnTiO}_{3}$ phase accompanying a $\mathrm{Zn}_{2} \mathrm{Ti}_{3} \mathrm{O}_{8}$ minor phase was observed. When annealing is at $900^{\circ} \mathrm{C}$, the results showed that single hexagonal $\mathrm{ZnTiO}_{3}$ phase is stable at $900^{\circ} \mathrm{C}$. It means that $\mathrm{ZnTiO}_{3}$ phase containing no $\mathrm{Mg}$ is unstable at $900^{\circ} \mathrm{C}$ and is decomposed from hexagonal $\mathrm{ZnTiO}_{3}$ to cubic $\mathrm{Zn}_{2} \mathrm{TiO}_{4}$ and rutile $\mathrm{TiO}_{2}$ at $900^{\circ} \mathrm{C}$. In addition, the effect of oxygen partial pressure for the films deposited on the phase transformations and microstructures of zinc titanites thin film was investigated.
\end{abstract}

\section{Introduction}

As the need for versatile electronic components with high reliability increases, the development of high-frequency electronic materials becomes imperative. Zinc titanate $\left(\mathrm{ZnTiO}_{3}\right)$ has been reported to have specific electrical properties that are adequate for applications in microwave dielectrics [1-3]. The $\mathrm{ZnO}-\mathrm{TiO}_{2}$ system exists in three forms: zinc metatitanate $\left(\mathrm{ZnTiO}_{3}\right)$ with a hexagonal ilmenite structure; zinc orthotitanate $\left(\mathrm{Zn}_{2} \mathrm{TiO}_{4}\right)$ with a cubic spinel crystal structure; zinc polytitanate $\left(\mathrm{Zn}_{2} \mathrm{Ti}_{3} \mathrm{O}_{8}\right)$ with a cubic defect spinel structure [4]. Steinike and Wallis. [5] have reported on $\mathrm{Zn}_{2} \mathrm{Ti}_{3} \mathrm{O}_{8}$ materials, a low-temperature form of $\mathrm{ZnTiO}_{3}$ existing at temperature $<820^{\circ} \mathrm{C}$. The $\mathrm{Zn}_{2} \mathrm{Ti}_{3} \mathrm{O}_{8}$ compound was formed based on the $\mathrm{Zn}_{2} \mathrm{TiO}_{4}$ phase [6]. However, hexagonal $\mathrm{ZnTiO}_{3}$ decomposes into cubic $\mathrm{Zn}_{2} \mathrm{TiO}_{4}$ and rutile $\mathrm{TiO}_{2}$ at $\mathrm{T}>945^{\circ} \mathrm{C}$ [7]. Moreover, a $\mathrm{ZnTiO}_{3}$ singlephase compound can be prepared by zinc oxide and rutile hydrate at $\mathrm{T}=850 \sim 900^{\circ} \mathrm{C}[4]$.

Pure $\mathrm{ZnTiO}_{3}$ shows good dielectric properties in the microwave range. It has a perovskite-type oxide structure and could be advantageous as a microwave resonator material
[8]. Furthermore, $\mathrm{ZnTiO}_{3}$ can be sintered at $1100^{\circ} \mathrm{C}$ without the use of sintering aids $[7,8]$. Moreover, when a sintering aid is added, it can be fired at temperatures below $900^{\circ} \mathrm{C}[9,10]$. $\mathrm{ZnTiO}_{3}$ has potential applications in gas sensors that detect ethanol or carbon monoxide. It is also a promising candidate for the use in nonlinear optics, as a luminescent material and in various photocatalytic roles $[11,12]$.

Pure zinc titanate thin films have been prepared by RF magnetron sputtering in previous studies [13]. It was shown that crystallization of the $\mathrm{ZnTiO}_{3}$ phase occurred at a substrate temperature of $400^{\circ} \mathrm{C}$ and annealing temperature of $700^{\circ} \mathrm{C}$ over $2 \mathrm{~h}$. However, as the annealing temperature exceeded $900^{\circ} \mathrm{C}$, the ilmenite $\mathrm{ZnTiO}_{3}$ decomposed into cubic $\mathrm{Zn}_{2} \mathrm{TiO}_{4}$ and rutile $\mathrm{TiO}_{2}$. In the present work, to suppress $\mathrm{ZnTiO}_{3}$ decomposition at $900^{\circ} \mathrm{C}, \mathrm{Mg}$-doped zinc titanate thin films were prepared by RF magnetron sputtering. The microstructure and phase transformation of $\mathrm{Mg}$-doped zinc titanate thin films with different annealing temperatures were subsequently investigated. In addition, the impact of different atmosphere $\left(\mathrm{Ar} / \mathrm{O}_{2}\right.$ ratio) during sputtering was investigated. 
TABLE 1: RF sputter conditions for the magnesium zinc titanate films.

\begin{tabular}{lc}
\hline Target & $\left(\mathrm{Zn}_{0.95} \mathrm{Mg}_{0.05}\right) \mathrm{TiO}_{3}$ \\
\hline Substrates & $\mathrm{SiO}_{2} / \mathrm{Si}$ \\
Target size in diameter $(\mathrm{mm})$ & 76.2 \\
Target to substrate distance $(\mathrm{mm})$ & 90 \\
RF power $(\mathrm{W})$ & 150 \\
Chamber pressure $(\mathrm{Pa})$ & $6.6 \times 10^{-4}$ \\
Working pressure $(\mathrm{Pa})$ & 2.5 \\
Sputtering gas & $\mathrm{Ar}$ \\
Ar flow $(\mathrm{sccm})$ & 50 \\
Substrate temperature $\left({ }^{\circ} \mathrm{C}\right)$ & 400 \\
Deposition time $(\mathrm{min})$ & 120 \\
Deposition rate $(\mathrm{nm} / \mathrm{min})$ & 1.4 \\
Substrate bias & Grounded \\
\hline
\end{tabular}

\section{Experimental Procedure}

The Mg-doped zinc titanates thin films were prepared by RF magnetron sputtering with the deposition conditions listed below.

A bulk magnesium zinc titanate target was synthesized by conventional solid-state methods from high-purity oxide powders; $\mathrm{MgO}, \mathrm{ZnO}$, and $\mathrm{TiO}_{2}$ (>99.9\%). The starting materials were mixed according to the stoichiometry of $\left(\mathrm{Zn}_{0.95} \mathrm{Mg}_{0.05}\right) \mathrm{TiO}_{3}$. The powder was then sintered and pressed into disks with a diameter of $76.2 \mathrm{~mm}$ and thickness of $3 \mathrm{~mm}$. These were subsequently used as $\left(\mathrm{Zn}_{0.95} \mathrm{Mg}_{0.05}\right) \mathrm{TiO}_{3}$ targets. The $\mathrm{Mg}$ content in the zinc titanate thin films was analyzed using electron spectroscopy for chemical analysis (ESCA), showing that the as-deposited thin films contained 2.77 at.\% Mg.

Magnesium zinc titanate thin films were fabricated onto $\mathrm{SiO}_{2} / \mathrm{Si}$ substrates using a $13.56 \mathrm{MHz}, 150 \mathrm{~W}$ RF magnetron sputtering system. The sputtering chamber was evacuated by an oil diffusion pump to a base pressure of $6.6 \times 10^{-4} \mathrm{~Pa}$. The sputtering gas Ar flow of $50 \mathrm{sccm}$ with a purity of $99.999 \%$ was introduced into the chamber with mass flow controllers and a working pressure of $2.5 \mathrm{~Pa}$. The target was cleaned at an RF power of $100 \mathrm{~W}$ for $5 \mathrm{~min}$ in an atmosphere of pure $\mathrm{Ar}$, and the substrate was covered with the shelter. The films were deposited at $400^{\circ} \mathrm{C}$ of substrate temperature. The asdeposited films were annealed at 600 to $900^{\circ} \mathrm{C}$ for 2 hours with a heating rate of $5^{\circ} \mathrm{C} / \mathrm{min}$ in air. The detailed deposition conditions of the zinc titanate films are listed in Table 1. For the different atmosphere, $\left(\mathrm{Ar} / \mathrm{O}_{2}\right.$ ratio) during sputtering was also carried out, the gas $\left(\mathrm{Ar}+\mathrm{O}_{2}\right)$ flow was fixed at 50 $\mathrm{sccm}$. The $\mathrm{O}_{2}$ gas flow was changed from 0 to $10 \mathrm{sccm}$.

Crystallinity of the films was analyzed by X-ray diffraction (XRD, Bruker D8A Germany), with $\mathrm{Cu} \mathrm{K} \alpha$ radiation for $2 \theta$ from $20^{\circ}$ to $80^{\circ}$ at a scan speed of $3^{\circ} \mathrm{min}^{-1}$ and a grazing angle of $0.5^{\circ}$ under $40 \mathrm{kV}$ and $40 \mathrm{~mA}$. The DIFFRAC plus TOPAS version 3.0 program was used to determine the lattice parameters. Microstructural and thickness observations of the cross-section and plane-view morphology of the thin films grown on $\mathrm{SiO}_{2} / \mathrm{Si}$ (100) substrates were analyzed using field-emission scanning electron microscope (FE-SEM, Hitachi S-4700 Japan). Microstructure of the films and the $\mathrm{ZnTiO}_{3} / \mathrm{SiO}_{2}$ interfaces were investigated by filed-emission transmission electron microscopy (FE-TEM, FEI E.O. Tecnai F20) at an acceleration voltage of $200 \mathrm{kV}$, equipped with energy-dispersive spectroscopy (EDS). Atomic force microscopy (AFM, Veeco CP-II) was used to study the surface topography, with a scanned area of $5 \mu \mathrm{m} \times 5 \mu \mathrm{m}$.

\section{Results and Discussion}

3.1. The Effect of $M g$ Dopant on the Phase Transformation of $\mathrm{ZnTiO}_{3}$ Thin Film. Figure 1 (a) shows the X-ray diffraction (XRD) patterns of the 2.77 at.\% Mg-doped zinc titanate thin films annealed at $600,700,800$, and $900^{\circ} \mathrm{C}$. It was observed that the as-deposited thin films were amorphous, indicating that no crystallization occurred in the as-deposited thin films. At $600^{\circ} \mathrm{C}$, the $\mathrm{Zn}_{2} \mathrm{Ti}_{3} \mathrm{O}_{8}$ peaks appeared, which is a low-temperature form of $\mathrm{ZnO}-\mathrm{TiO}_{2}$ system, as reported by Yamaguchi et al. [14]. $\mathrm{Zn}_{2} \mathrm{Ti}_{3} \mathrm{O}_{8}$ is a stable or metastable compound; its existence was first reported by Bartram and Slepetys [4], who found that it decomposes at temperatures above $700^{\circ} \mathrm{C}$, and $\mathrm{Zn}_{2} \mathrm{Ti}_{3} \mathrm{O}_{8}$ can be existed stably between 600 to $700^{\circ} \mathrm{C}[4,6]$. However, the intensity of peaks increased rapidly up to $700^{\circ} \mathrm{C}$. The majority crystalline phase was identified as hexagonal $\mathrm{ZnTiO}_{3}$, accompanied by $\mathrm{Zn}_{2} \mathrm{Ti}_{3} \mathrm{O}_{8}$ minor phases.

As the annealing temperature was increased to $800^{\circ} \mathrm{C}$, the hexagonal $\mathrm{ZnTiO}_{3}$ became a single crystalline phase. The intensity of the (104) peak was higher than the other peaks of the $\mathrm{ZnTiO}_{3}$ films, indicating that there is a high degree of (104)-oriented $\mathrm{ZnTiO}_{3}$ on the $\mathrm{SiO}_{2} / \mathrm{Si}(100)$ substrates. Chen and Huang. [15] have shown that (100)-oriented $\mathrm{MgTiO}_{3}$ films were obtained on the Si substrate. The preferred orientation tends to reduce the free energy to reach a stable state. When the temperature was further increased to $900^{\circ} \mathrm{C}$, the $\mathrm{ZnTiO}_{3}$ single phase was remained. This result is unlike pure zinc titanate thin films where the hexagonal $\mathrm{ZnTiO}_{3}$ phase decomposes into $\mathrm{TiO}_{2}$ and $\mathrm{Zn}_{2} \mathrm{TiO}_{4}$ at $900^{\circ} \mathrm{C}$, as shown in Figure 1 (b).

Figure 2 shows the SEM micrographs of the Mg-doped zinc titanate thin films deposited on $\mathrm{SiO}_{2} / \mathrm{Si}$ substrate annealed at different temperatures. The grain size increased with the annealing temperatures. The grain sizes of specimens for $700^{\circ}, 800^{\circ}$, and $900^{\circ} \mathrm{C}$ are $25 \mathrm{~nm}, 139 \mathrm{~nm}$, and $208 \mathrm{~nm}$, respectively. To prove that pure $\mathrm{ZnTiO}_{3}$ phase exist in $\mathrm{Mg}$-doped zinc titanate thin films at $900^{\circ} \mathrm{C}$, high resolution TEM was used to analyze these $\mathrm{Mg}$-doped $\mathrm{ZnTiO}_{3}$ thin films. Figure 3 shows the cross-section of Mg-doped $\mathrm{ZnTiO}_{3}$ thin films on $\mathrm{SiO}_{2} / \mathrm{Si}$ substrate. The HRTEM of region 1 and 2 shows the d-spacing of h- $\mathrm{ZnTiO}_{3}$ phase, which is $d_{003}=0.441 \mathrm{~nm}$ and $0.449 \mathrm{~nm}$, respectively. The XRD analysis revealed a similar trend. Comprehensively, the results confirmed that $\mathrm{ZnTiO}_{3}$ thin films were successfully prepared at $900^{\circ} \mathrm{C}$. Interestingly, a twin is observed as shown in Figure 3 (a), this is a two-dimensional defect. A twin is defined as a region in which a mirror image of the structure exists across a plane or a boundary. This defect is often due to an atomic lattice defect forming a mirror image of 


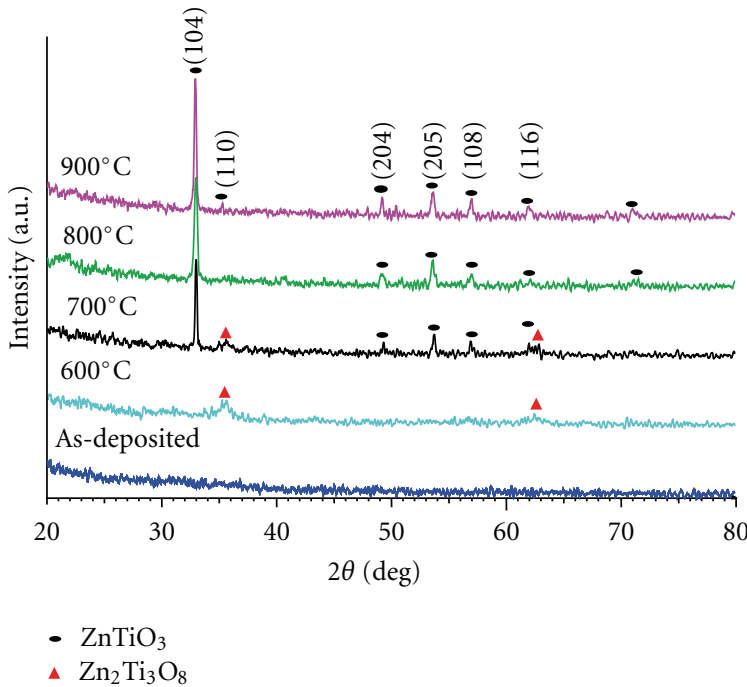

(a)

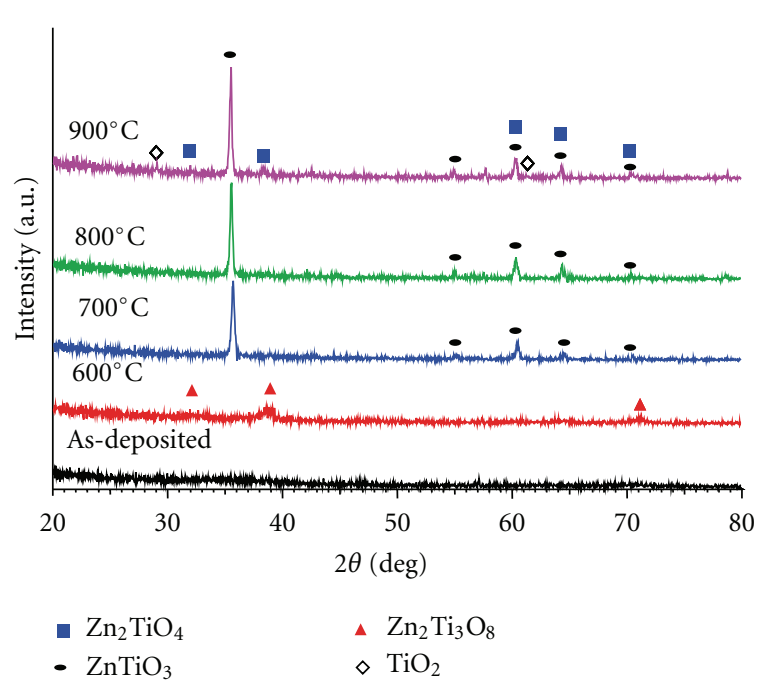

(b)

FigURE 1: X-ray diffraction patterns of thin films annealed at different temperatures, (a) Mg-doped zinc titanates thin film and (b) pure zinc titanates thin film.

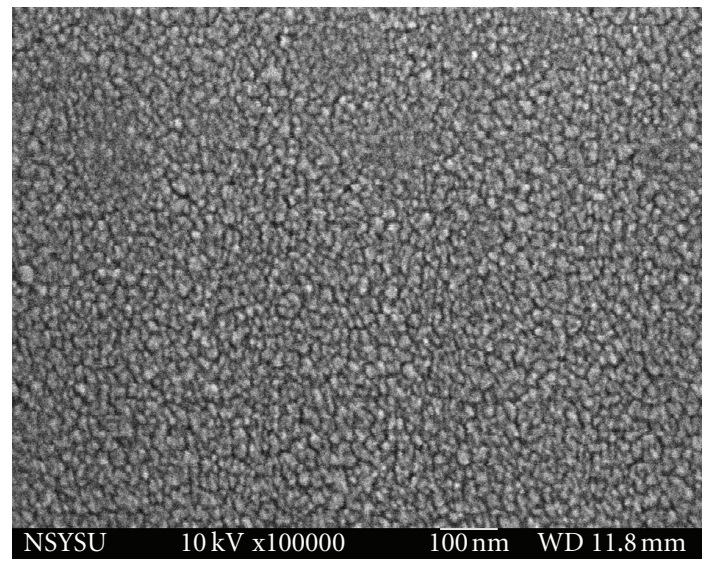

(a)

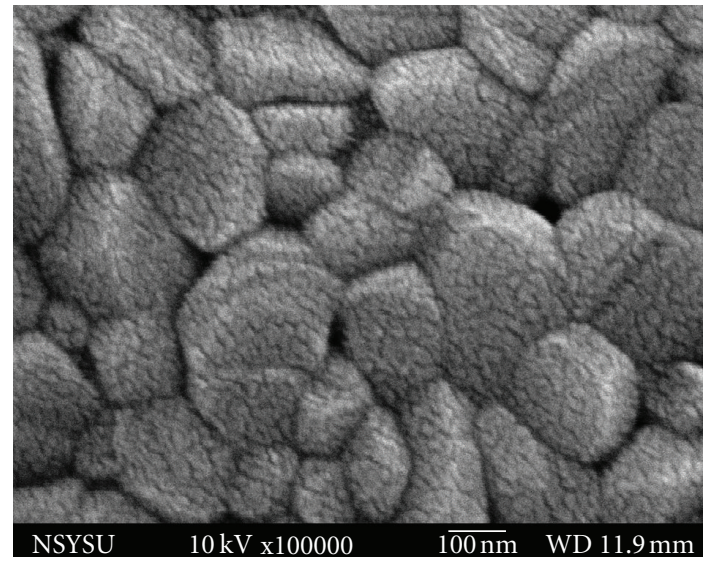

(c)

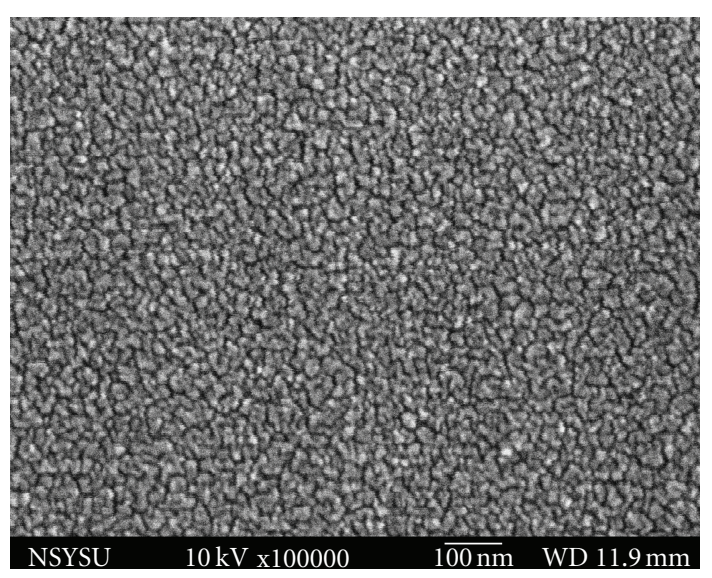

(b)

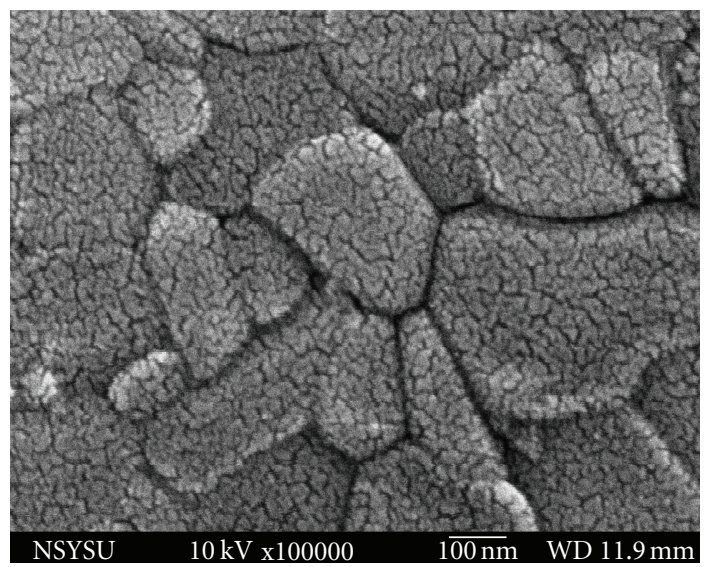

(d)

FigurE 2: The SEM micrographs of Mg-doped zinc titanates thin films annealed at (a) as-deposited, (b) $700^{\circ} \mathrm{C}$, (c) $800^{\circ} \mathrm{C}$, and (d) $900^{\circ} \mathrm{C}$. 


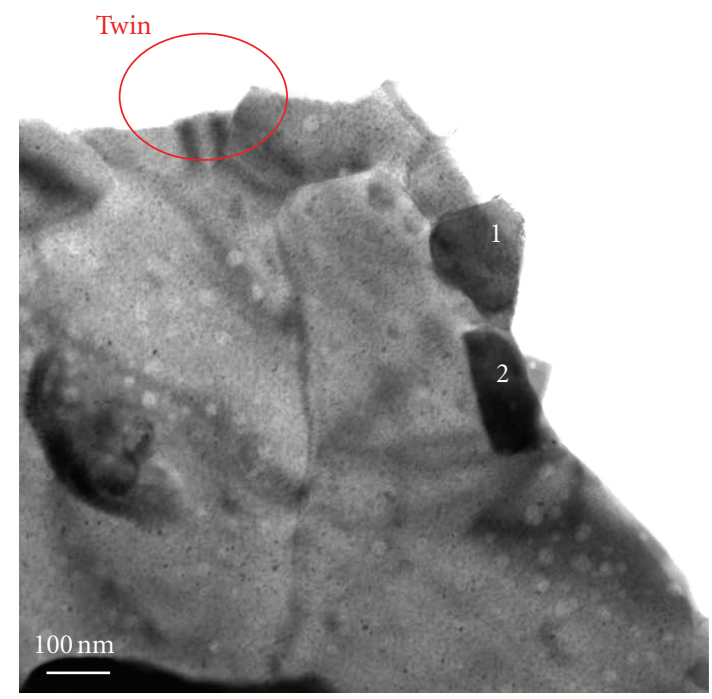

(a)

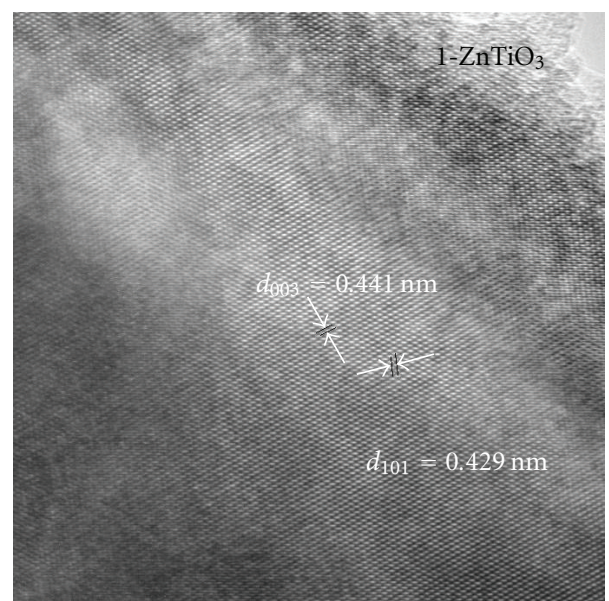

(b)

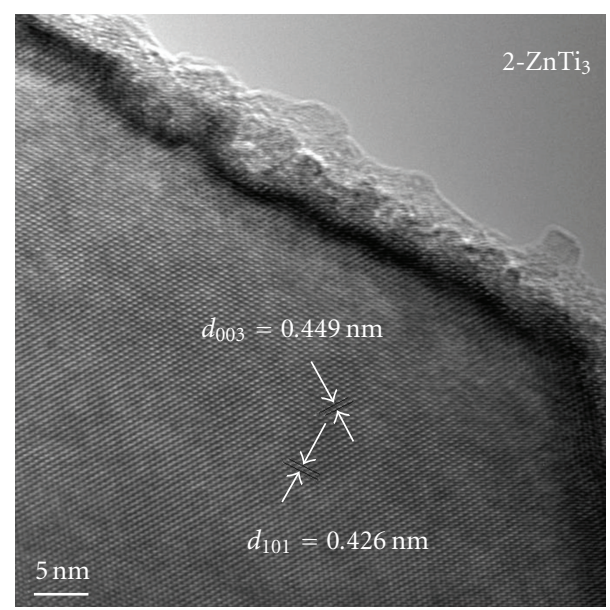

(c)

Figure 3: TEM micrographs of the zinc titanates thin films with $\mathrm{Mg}$ dopant annealed at $800^{\circ} \mathrm{C}$. (a) Twin, (b) region 1 of $\mathrm{ZnTiO}_{3}$ grain, and (c) region 2 of $\mathrm{ZnTiO}_{3}$ grain.

undeformed lattice next to it. Based on the above results, it can be expected that the $\mathrm{Zn}$ atoms are substituted with $\mathrm{Mg}$ atoms in the $\mathrm{ABO}_{3}$ structure. This may be attributed to the ionic radius of $\mathrm{Mg}^{2+}(0.66 \AA)$, which is smaller than that of $\mathrm{Zn}^{2+}(0.74 \AA)$ [16, 17]. Hence, when $\mathrm{Mg}^{2+}$ substitutes on $\mathrm{Zn}^{2+}$ sites in the $\mathrm{ABO}_{3}$ structure, lattice strain will be created.

\subsection{The Effect of Oxygen Partial Pressure on the Phase Trans-} formation of $\mathrm{ZnTiO}_{3}$ Thin Film. The effect of oxygen partial pressure on the phase transformation of zinc titanates thin films was also investigated. The different atmosphere $\left(\mathrm{Ar} / \mathrm{O}_{2}\right.$ ratio) during sputtering was carried out in this experiment. Table 2 lists the element analysis of zinc titanites thin films using ESCA equipment. It is found that the $\mathrm{Zn} / \mathrm{Ti}$ ratio decreased significantly when $\mathrm{O}_{2}$ was used in the chamber. The compositions at different oxygen partial pressures are different from target composition, which results from the different striking coefficients and variation in sputtering yields of the constituent elements [18]. During sputtering, the target atoms are subject to collisions with gas atoms or molecules left in the chamber and other ejected atoms, resulting in a partial loss of energy and direction on their way to the substrate [19]. Because oxygen gas is biatom molecule and its radius is much larger than Ar, the sputtered particles suffer from more collision when more oxygen partial pressure is introduced. This changes the composition of thin film.

XRD measurements were performed to examine the variation of structural properties with varying oxygen partial pressures $\left(P_{\mathrm{O}_{2}}\right)$. Figure 4 shows the XRD spectra of zinc titanate thin films grown under different $\mathrm{Ar}$ and $\mathrm{O}_{2}$ ratios, and these films were annealed at $800^{\circ} \mathrm{C}$. For an $\mathrm{Ar} / \mathrm{O}_{2}$ ratio of 9: $1\left(10 \% \mathrm{O}_{2}\right)$, the $\mathrm{ZnTiO}_{3}$ and $\mathrm{Zn}_{2} \mathrm{Ti}_{3} \mathrm{O}_{8}$ phases coexisted as shown in Figure 4 (b). This result indicates that $10 \% \mathrm{O}_{2}$ in the sputtering atmosphere leads to the remaining $\mathrm{Zn}_{2} \mathrm{Ti}_{3} \mathrm{O}_{8}$ phase at $800^{\circ} \mathrm{C}$, because the $\mathrm{Zn}_{2} \mathrm{Ti}_{3} \mathrm{O}_{8}$ phase is stable 


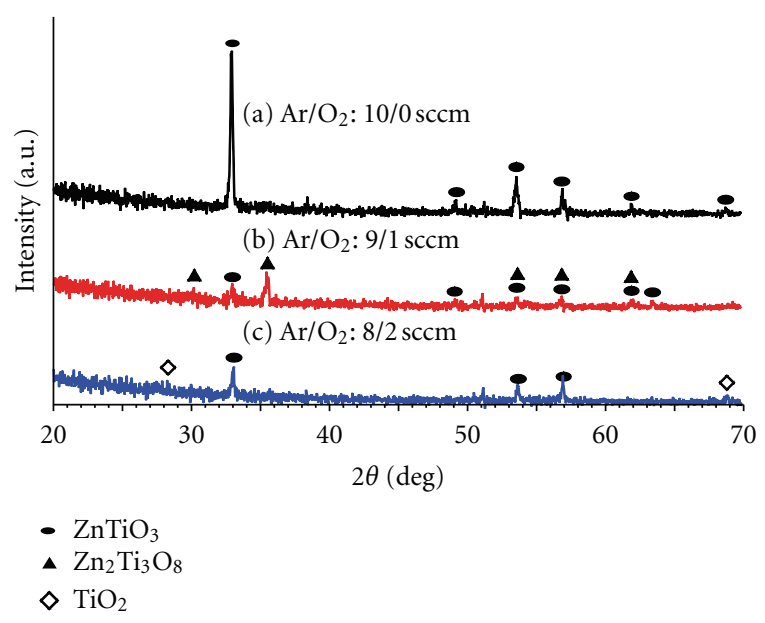

FIGURE 4: X-ray diffraction patterns of the zinc titanates thin films deposited at RF power: $200 \mathrm{~W}$, substrate temperature of $400^{\circ} \mathrm{C}$, and then annealed at $800^{\circ} \mathrm{C}$ with different $\mathrm{Ar}$ to $\mathrm{O}_{2}$ ratio (a) $10: 0$, (b) $9: 1$ and (c) $8: 2$.

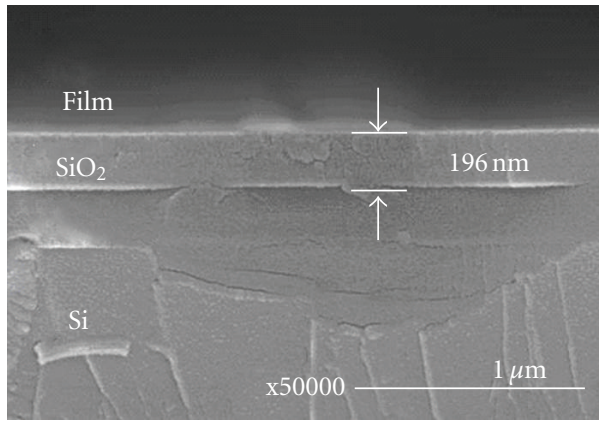

(a)

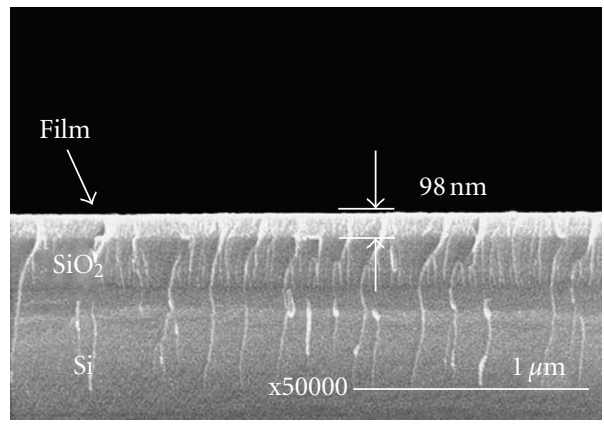

(b)

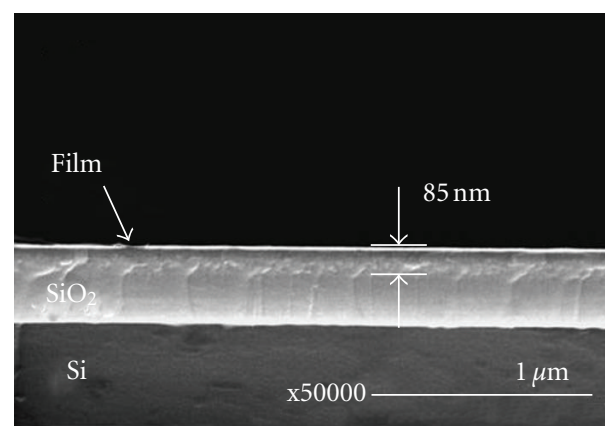

(c)

Figure 5: The film thickness of the zinc titanate deposited at $400^{\circ} \mathrm{C}$ of substrate temperature and then annealed at $800^{\circ} \mathrm{C}$ with different $\mathrm{Ar}$ to $\mathrm{O}_{2}$ ratio (a) $10: 0$, (b) $9: 1$, and (c) $8: 2$.

TABLE 2: The elements analysis of zinc titanate thin films at different oxygen partial pressure was measured using ESCA equipment.

\begin{tabular}{lcccr}
\hline $\begin{array}{l}\text { Substrate } \\
\text { temperature }\left({ }^{\circ} \mathrm{C}\right)\end{array}$ & \multicolumn{3}{c}{ Oxygen partial pressure } & \multicolumn{2}{c}{ Surface element composition, $\mathrm{X} \%$} \\
\hline 400 & $\left(\right.$ Ar to $\mathrm{O}_{2}$ ratio) & $\mathrm{Zn} 2 \mathrm{p}$ & $\mathrm{Ti2p}$ & $\mathrm{O} 1 \mathrm{~s}$ \\
400 & $50 / 0(10: 0)$ & 13.23 & 20.55 & 63.19 \\
400 & $45 / 5(9: 1)$ & 11.07 & 22.22 & 65.57 \\
\end{tabular}




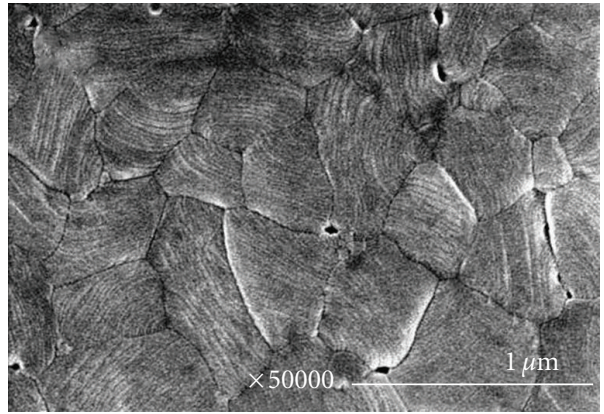

(a)

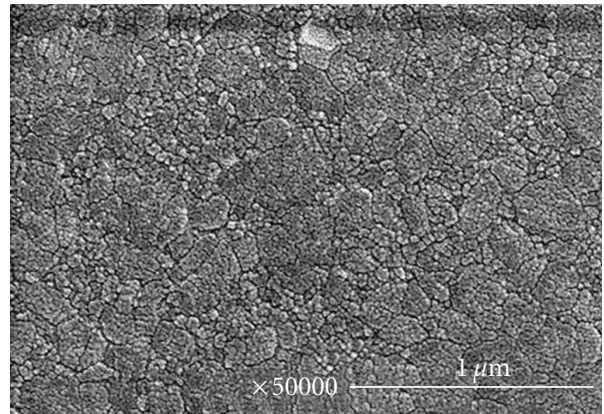

(b)

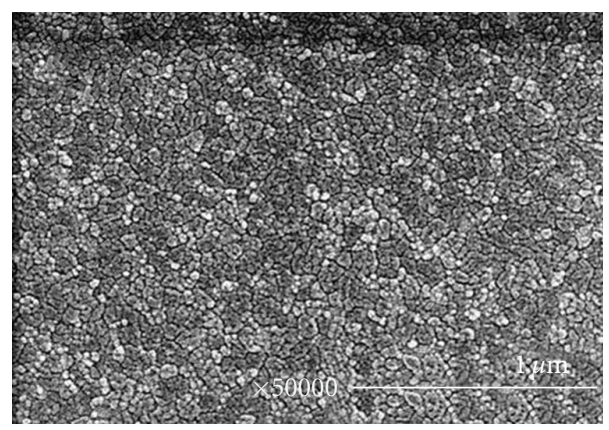

(c)

Figure 6: Plane-view SEM micrographs of zinc titanate thin film deposited at $400^{\circ} \mathrm{C}$ of substrate temperature and then annealed at $800^{\circ} \mathrm{C}$ with different Ar to $\mathrm{O}_{2}$ ratio (a) $10: 0$, (b) 9:1, and (c) $8: 2$.

below $700^{\circ} \mathrm{C}$ without oxygen in the atmosphere, as seen in Figure 4 (a). However, when the $\mathrm{O}_{2}$ partial pressure was increased to $20 \%\left(\mathrm{Ar} / \mathrm{O}_{2}\right.$ ratio of $\left.8: 2\right)$, the major and minor phases were $\mathrm{ZnTiO}_{3}$ and $\mathrm{TiO}_{2}$ phases, respectively. This result indicates that $20 \% \mathrm{O}_{2}$ in the sputtering atmosphere leads to the decomposition of the $\mathrm{Zn}_{2} \mathrm{Ti}_{3} \mathrm{O}_{8}$ phase into $\mathrm{ZnTiO}_{3}$ and $\mathrm{TiO}_{2}$ at $800^{\circ} \mathrm{C}$ as shown in Figure 4 (c). Hence, there are two phases present at $800^{\circ} \mathrm{C}$ when $\mathrm{O}_{2}$ is used: $\mathrm{Zn}_{2} \mathrm{Ti}_{3} \mathrm{O}_{8}$ and $\mathrm{TiO}_{2}$. According to the phase diagram of $\mathrm{ZnO}-\mathrm{TiO}_{2}[4], \mathrm{TiO}_{2}$ appears at $945^{\circ} \mathrm{C}$ and $\mathrm{Zn}_{2} \mathrm{Ti}_{3} \mathrm{O}_{8}$ exists below $700^{\circ} \mathrm{C}$. It is believed that the evolution of the phases is related to the variation of oxygen partial pressure. From Table 2, it is noticed that the oxygen partial pressure causes the compositional change of zinc titanates thin films. The variation in composition (especially $\mathrm{Zn}$ concentration) may result in the different phase transformations: lower $\mathrm{Zn}$ concentration leads to form $\mathrm{Zn}_{2} \mathrm{Ti}_{3} \mathrm{O}_{8}$ or $\mathrm{TiO}_{2}$. In addition, $\mathrm{Zn}$ concentration in zinc titanates thin film may be reduced again during annealing, because zinc is easy to vaporize at high temperature. Therefore, it cannot be formed a $\mathrm{ZnTiO}_{3}$ due to lower $\mathrm{Zn}$ concentration.

The film thickness with varying $\mathrm{O}_{2}$ partial pressure $\left(P_{\mathrm{O}_{2}}\right)$ was measured using the cross-section of FE-SEM micrographs as shown in Figure 5. The cross-sectional views show that the thicknesses of the films significantly decrease when a small amount of oxygen is added to the sputtering ambient and subsequently decreases slowly as the oxygen partial pressure increases. The thicknesses of the films were 196, 98, and $85 \mathrm{~nm}$ for pure Ar and Ar: $\mathrm{O}_{2}$ flow ratios of $9: 1$ and $8: 2$, respectively. The gradual decrease in thickness with increase of the oxygen partial pressure can be explained by the smaller sputtering yields of oxygen ions than argon ions; the momentum transfer of oxygen is smaller than that of argon during ionic bombardment [20]. However, the thickness difference between the films that are grown with and without oxygen is too significant to be explained only by the momentum transfer process [21]. In addition, according to XRD analysis (Figure 4), increasing the oxygen partial pressure was found to degrade the crystallinity of the zinc titanites thin films due the formation of oxygen-induced defects $[22,23]$.

Plane-view SEM micrographs of zinc titanate thin film deposited at $400^{\circ} \mathrm{C}$ substrate temperature and then annealed at $800^{\circ} \mathrm{C}$ with different $\mathrm{Ar}$ to $\mathrm{O}_{2}$ ratio are shown in Figure 6. As one can see, the grain size decreased with increasing $\mathrm{O}_{2}$ partial pressure. According to XRD analysis, the phases of the thin film also differ with $\mathrm{O}_{2}$ partial pressure. Moreover, it is found that there are two kinds of grains in the $10 \% P_{\mathrm{O}_{2}}$ samples as shown in Figure 6 (b). According to XRD analysis (Figure 4), $\mathrm{ZnTiO}_{3}$ grains and $\mathrm{Zn}_{2} \mathrm{Ti}_{3} \mathrm{O}_{8}$ grains are identified. The surface morphologies of zinc titanite films have been observed with AFM, and the results are shown in Figure 7, corresponding to the samples prepared at oxygen partial pressures of $0 \%$ and $10 \%$. The left figures display the surface morphologies and the pictures on the right depicts typical three-dimensional representations $(1000 \mathrm{~nm}$ by $1000 \mathrm{~nm}$ surface plots). All the films present a rough surface texture, consisted of particles fused together, building up high mountains and deep valleys. All the films can be described as a contiguous network of particles and aggregates 


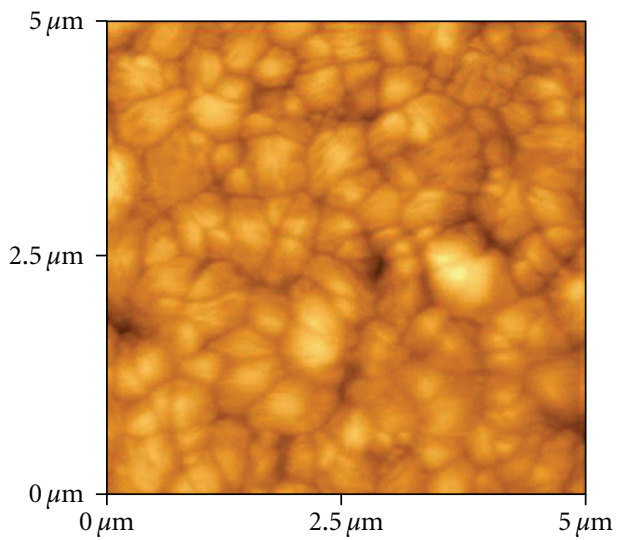

(a)

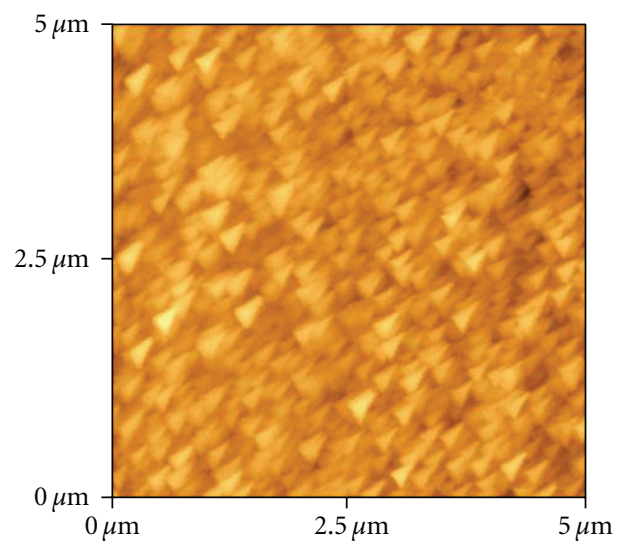

(c)

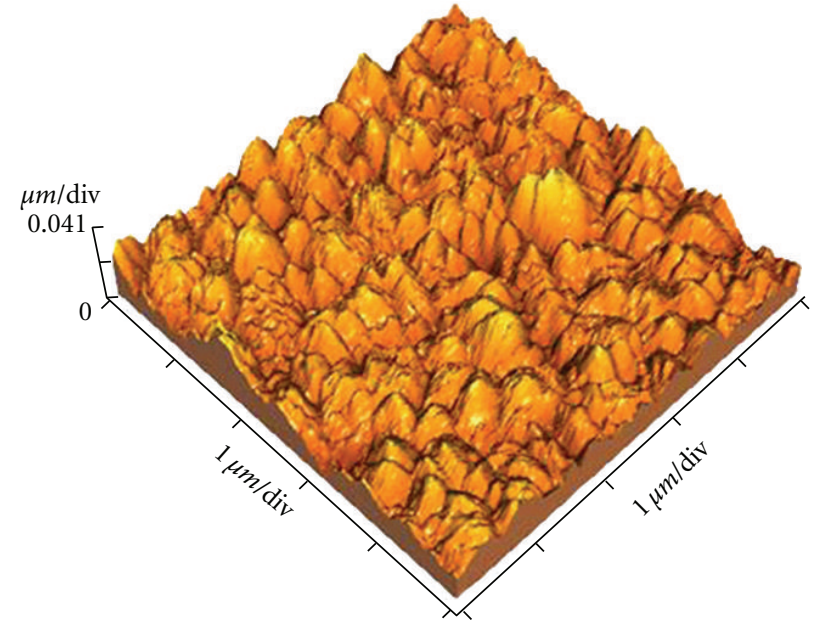

(b)

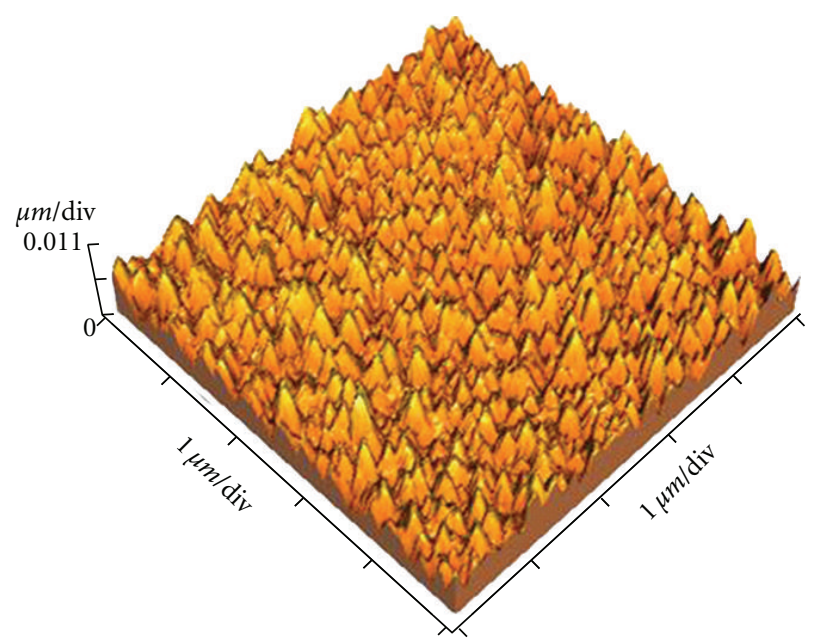

(d)

FIgURE 7: AFM surface morphologies and the right pictures depict typical three-dimensional representations $(1000 \mathrm{~nm} \times 1000 \mathrm{~nm}$ surface plots) of the zinc titanate thin films deposited at $400^{\circ} \mathrm{C}$ of substrate temperature and then annealed at $800^{\circ} \mathrm{C}$ : (a) and (b) Ar to $\mathrm{O}_{2}$ ratio 10 : 0 , and (c) and (d) Ar to $\mathrm{O}_{2} 9: 1$.

with significant roughness. It is also shown that the $\mathrm{TiO}_{2}$ particles decrease in size with an increase in oxygen partial pressure, which may be ascribed to the deposition rate.

\section{Conclusion}

The effects of $\mathrm{Mg}$ doping on zinc titanate thin films were investigated using a variety of analytical tools. The microstructure and phase transformation of zinc titanate thin films can be influenced by doping Mg. It is found that the as-deposited films were amorphous, as confirmed by the XRD results. The results showed that single $\mathrm{Zn}_{2} \mathrm{Ti}_{3} \mathrm{O}_{8}$ existed when the films were annealed at $600^{\circ} \mathrm{C}$. When annealing was conducted at $700^{\circ} \mathrm{C}$, the results revealed that the majority phase was hexagonal $\mathrm{ZnTiO}_{3}$, accompanied by minority amounts of $\mathrm{Zn}_{2} \mathrm{Ti}_{3} \mathrm{O}_{8}$. Unlike pure zinc titanate films, this result shows that the $\mathrm{Zn}_{2} \mathrm{Ti}_{3} \mathrm{O}_{8}$ phase can exist at temperatures above $700^{\circ} \mathrm{C}$. However, there is no decomposition from hexagonal $\mathrm{ZnTiO}_{3}$ to cubic $\mathrm{Zn}_{2} \mathrm{TiO}_{4}$ and rutile $\mathrm{TiO}_{2}$ took place with a further increase in temperature to $900^{\circ} \mathrm{C}$. It means that the addition of $\mathrm{Mg}$ to $\mathrm{ZnTiO}_{3}$ compound increases its stability up to $900^{\circ} \mathrm{C}$. In addition, with increasing oxygen partial pressure (Ar-to- $\mathrm{O}_{2}$ ratio decreased from $10: 0$ to $8: 2$ ), the phase transformations versus temperatures changed. At an Ar-to- $\mathrm{O}_{2}$ ratio of 9:1, $\mathrm{ZnTiO}_{3}$ and $\mathrm{Zn}_{2} \mathrm{Ti}_{3} \mathrm{O}_{8}$ phases coexisted at $800^{\circ} \mathrm{C}$. By increasing the $P_{\mathrm{O} 2}$ partial pressure to $8: 2$, the $\mathrm{ZnTiO}_{3}$ phase remained as the main phase, accompanied by a $\mathrm{TiO}_{2}$ minor phase at $800^{\circ} \mathrm{C}$

\section{Acknowledgment}

The authors would like to acknowledge the financial support of this research by the National Science Council of Taiwan under Contract no. NSC-98-2221-E-020-003. 


\section{References}

[1] C. F. Shih, W. M. Li, M. M. Lin, and K. T. Hung, "Zinc titanates sintered from $\mathrm{ZnO}$ and $\mathrm{TiO}_{2}$ nanowires prepared by a hydrothermal process," Journal of the Electrochemical Society, vol. 156, no. 1, pp. E13-E17, 2009.

[2] Y. C. Lee, W. H. Lee, and F. T. Shiao, "Microwave dielectric properties of $\mathrm{Zn}_{0.95} \mathrm{Mg}_{0.05} \mathrm{TiO}_{3}+0.25 \mathrm{TiO}_{2}$ ceramics with $3 \mathrm{ZnO}-\mathrm{B}_{2} \mathrm{O}_{3}$ addition," Japanese Journal of Applied Physics Part 1, vol. 43, no. 11, pp. 7596-7599, 2004.

[3] E. Hosono, S. Fujihara, M. Onuki, and T. Kimura, "Lowtemperature synthesis of nanocrystalline zinc titanate materials with high specific surface area," Journal of the American Ceramic Society, vol. 87, no. 9, pp. 1785-1788, 2004.

[4] S. F. Bartram and R. A. Slepetys, "Compound formation and crystal structure in the system $\mathrm{ZnO}-\mathrm{TiO}_{2}$," Journal of American Ceramics Society, vol. 44, no. 10, pp. 493-499, 1961.

[5] U. Steinike and B. Wallis, "Formation and structure of Ti-Znoxides," Crystal Research and Technology, vol. 32, no. 1, pp. 187-193, 1997.

[6] H. T. Kim, Y. Kim, M. Valant, and D. Suvorov, "Titanium incorporation in $\mathrm{Zn}_{2} \mathrm{TiO}_{4}$ spinel ceramics," Journal of the American Ceramic Society, vol. 84, no. 5, pp. 1081-1086, 2001.

[7] F. H. Dulin and D. E. Rase, "Phase equilibria in the system $\mathrm{ZnO}-\mathrm{TiO}_{2}$," Journal of the American Ceramic Society, vol. 43, pp. 125-128, 1960.

[8] H. T. Kim, S. H. Kim, S. Nahm, J. D. Byun, and Y. Kim, "Lowtemperature sintering and microwave dielectric properties of zinc metatitanate-rutile mixtures using boron," Journal of the American Ceramic Society, vol. 82, no. 11, pp. 3043-3048, 1999.

[9] Y. C. Lee and W. H. Lee, "Effects of glass addition on microwave dielectric properties of $\mathrm{Zn}_{0.95} \mathrm{Mg}_{0.05} \mathrm{TiO}_{3}+0.25$ $\mathrm{TiO}_{2}$ ceramics," Japanese Journal of Applied Physics Part 1, vol. 44, no. 4 A, pp. 1838-1843, 2005.

[10] A. Chaouchi, M. Aliouat, S. Marinel, S. d'Astorg, and H. Bourahla, "Effects of additives on the sintering temperature and dielectric properties of $\mathrm{ZnTiO}_{3}$ based ceramic," Ceramics International, vol. 33, no. 2, pp. 245-248, 2007.

[11] A. B. Bodade, A. M. Bende, and G. N. Chaudhari, "Synthesis and characterization of CdO-doped nanocrystalline $\mathrm{ZnO}: \mathrm{TiO}_{2}$-based $\mathrm{H}_{2} \mathrm{~S}$ gas sensor," Vacuum, vol. 82, no. 6, pp. 588-593, 2008.

[12] D. Barreca, E. Comini, A. P. Ferrucci et al., "First example

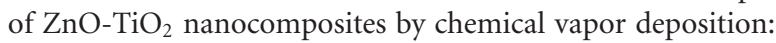
structure, morphology, composition, and gas sensing performances," Chemistry of Materials, vol. 19, no. 23, pp. 5642 5649, 2007.

[13] Y. C. Lee, Y. L. Huang, W. H. Lee, and F. S. Shieu, "Formation and transformation of $\mathrm{ZnTiO}_{3}$ prepared by sputtering process," Thin Solid Films, vol. 518, no. 24, pp. 7366-7371, 2010.

[14] O. Yamaguchi, M. Morimi, H. Kawabata, and K. Shimizu, "Formation and transformation of $\mathrm{ZnTiO}_{3}$," Journal of the American Ceramic Society, vol. 70, no. 5, pp. C97-C98, 1987.

[15] Y. B. Chen and C. L. Huang, "Properties of $\mathrm{MgTiO}_{3}$ thin films prepared by RF magnetron sputtering for microwave application," Journal of Crystal Growth, vol. 282, no. 3-4, pp. 482-489, 2005.

[16] M. V. Nikolic, N. Obradovic, K. M. Paraskevopoulos, T. T. Zorba, S. M. Savic, and M. M. Ristic, "Structural analysis of $\mathrm{Zn}_{2} \mathrm{TiO}_{4}$ doped with MgO," Powder Metallurgy and Metal Ceramics, vol. 48, no. 11-12, pp. 712-717, 2009.
[17] M. L. Hsieh, L. S. Chen, H. C. Hsu, S. Wang, M. P. Houng, and S. L. Fu, "Effect of oxide additives on the lowtemperature sintering of dielectrics $(\mathrm{Zn}, \mathrm{Mg}) \mathrm{TiO}_{3}$," Materials Research Bulletin, vol. 43, no. 11, pp. 3122-3129, 2008.

[18] Y. Li, S. Zhang, T. Sritharan, Y. Liu, and T. P. Chen, "Influence of oxygen partial pressure on magnetron sputtered $\mathrm{Sr}_{0.8} \mathrm{Nd}_{0.3} \mathrm{Bi}_{2.5} \mathrm{Ta}_{2} \mathrm{O}_{9+x}$ ferroelectric thin films," Journal of Alloys and Compounds, vol. 457, no. 1-2, pp. 549-554, 2008.

[19] R. B. H. Tahar, T. Ban, Y. Ohya, and Y. Takahashi, "Tin doped indium oxide thin films: electrical properties," Journal of Applied Physics, vol. 83, no. 5, pp. 2631-2645, 1998.

[20] H. F. Winters and P. Sigmund, "Sputtering of chemisorbed gas (nitrogen on tungsten) by low-energy ions," Journal of Applied Physics, vol. 45, no. 11, pp. 4760-4766, 1974.

[21] J. H. Kim, J. H. Lee, Y. W. Heo, J. J. Kim, and J. O. Park, “Effects of oxygen partial pressure on the preferential orientation and surface morphology of ITO films grown by RF magnetron sputtering," Journal of Electroceramics, vol. 23, no. 2-4, pp. 169-174, 2009.

[22] S. Lee, H. S. Lee, S. J. Hwang, Y. Shon, D. Y. Kim, and E. K. Kim, "Effects of oxygen partial pressure during sputtering growth on physical properties of $\mathrm{Zn}_{0.93} \mathrm{Mn}_{0.07} \mathrm{O}$ thin films," Journal of Crystal Growth, vol. 286, no. 2, pp. 223-227, 2006.

[23] Q. Xiao, H. He, S. Shao, J. Shao, and Z. Fan, "Influences of deposition rate and oxygen partial pressure on residual stress and microstructure of YSZ thin films," Thin Solid Films, vol. 517, no. 15, pp. 4295-4298, 2009. 

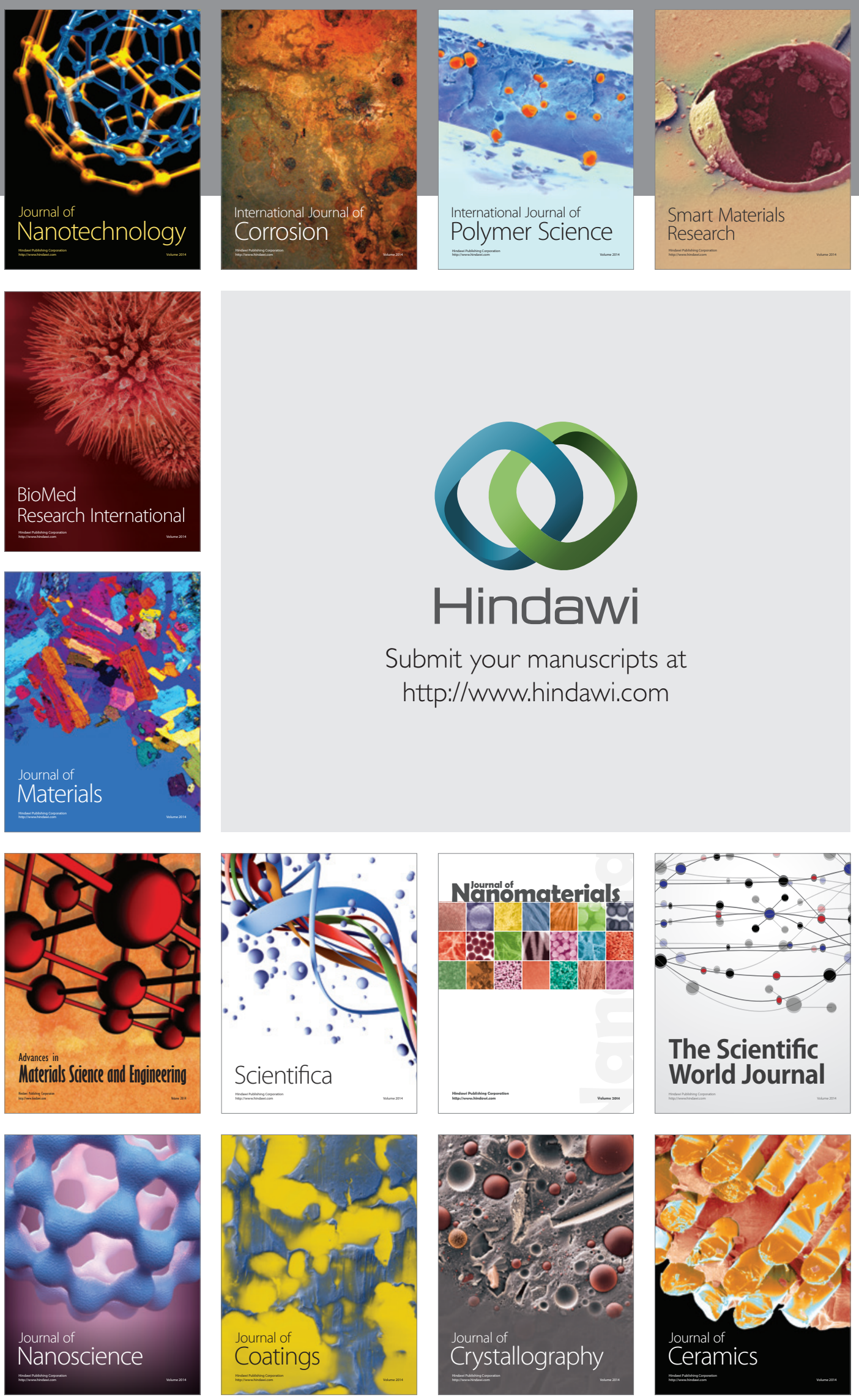

The Scientific World Journal

Submit your manuscripts at

http://www.hindawi.com

\section{World Journal}

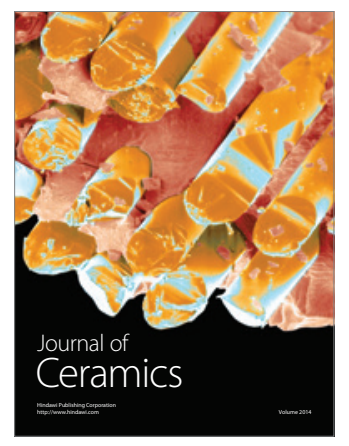

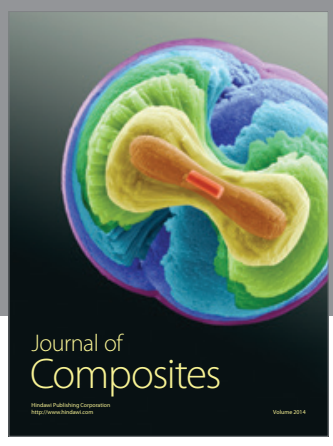
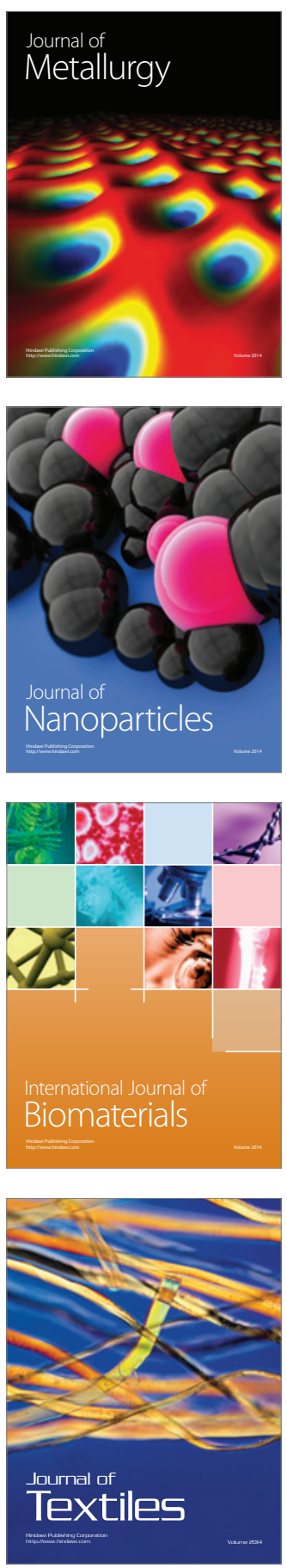